SUMMARY OF REPORTED AGRICULTURE AND IRRIGATION WATER USE IN LONOKE COUNTY, ARKANSAS, 1991

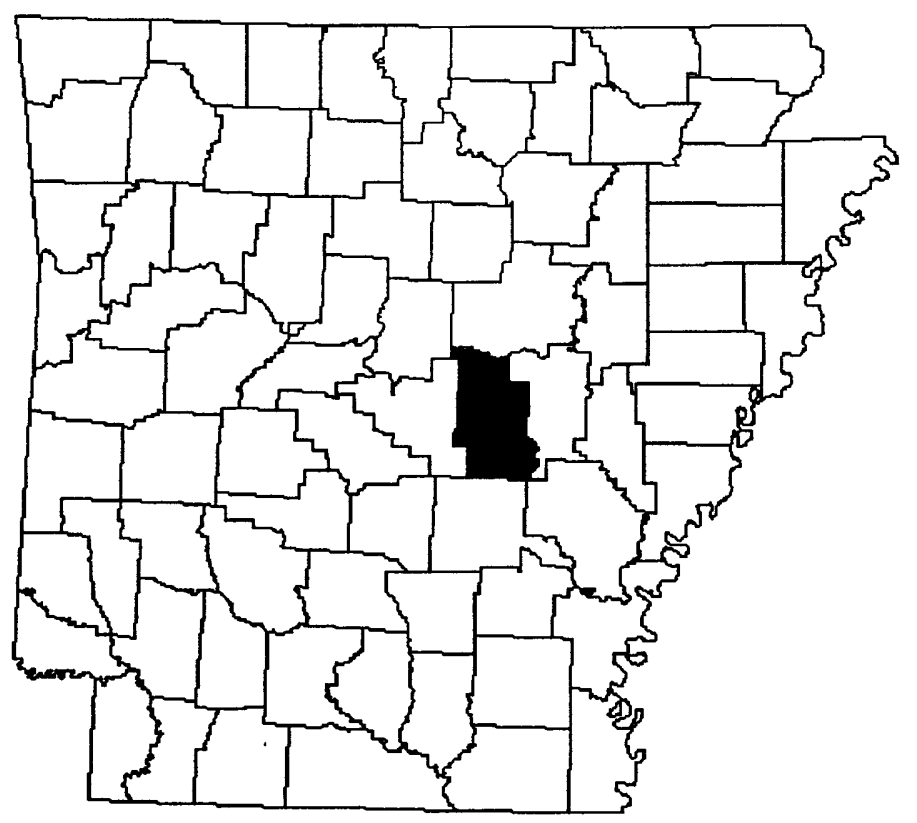

U.S. Department of the Interior U.S. Geological Survey Open-File Report 93-471

Prepared in cooperation with the Arkansas Soil and Water Conservation Commission 


\title{
SLMMARY OF REPORTED AGRICULTURE AND IRRIGATION WATER USE IN LONOKE COUNTY, ARKANSAS, 1991
}

\author{
By Terrance W. Holland ${ }^{1}$, Carolyn A. Manning ${ }^{2}$, \\ and Kenneth L. Stafford ${ }^{1}$
}

Water is one of Arkansas' most valuable resources. Site-specific water-use data for several categories are collected and compiled annually by the Arkansas Soil and Water Conservation Commission (ASWCC) in cooperation with the U.S. Geological Survey. Data for the agriculture (non-irrigation) and irrigation categories are reported through the Conservation District Offices in each county.

This report summarizes the 1991 water-use reporting through the Conservation District Office in Lonoke County, Arkansas. The number of withdrawal registrations for Lonoke County was 3,313 (2,587 ground water and 726 surface water). Water withdrawals reported during the registration process total 61.30 million gallons per day (Mgal/d) $(59.50 \mathrm{Mgal} / \mathrm{d}$ ground water and $1.80 \mathrm{Mgal} / \mathrm{d}$ surface water) for agriculture and $300.45 \mathrm{Mgal} / \mathrm{d}(241.86 \mathrm{Mgal} / \mathrm{d}$ ground water and $58.59 \mathrm{Mgal} / \mathrm{d}$ surface water) for irrigation.

Of the total amount of water withdrawn $(361.75 \mathrm{Mgal} / \mathrm{d})$, 402,880 acre-feet per year (359.71 Mgal/d) can be accounted for by application type (table 1). The registration reports for 1991 indicate that this water was applied to 238,457 acres of land to irrigate rice, sorghum, corn, soybeans, milo, cash grains, cotton, and sod, as well as for the agricultural uses of animal aquaculture, hatcheries, and ducks. There is a difference between total amount of water withdrawn and the reported quantity of water applied for agriculture and irrigation (2.04 Mgal/d) because some water is diverted to holding reservoirs, and because crop type or acreage delineation are incomplete on some reporting forms.

Water-use data collected in Lonoke County are used in various State/Federal/Cooperative projects. The objectives of these projects are to enhance the water-resources knowledge base and to provide water managers with the best possible information to help ensure that water of suitable quality continues to be available in sufficient quantities to meet water demands. Current projects include: the Eastern Arkansas Optimization modeling project and the National Water Use Information Program.

\footnotetext{
${ }^{1}$ U.S. Geological Survey

2 Arkansas Soil and Water Conservation Commission
} 
Ground- and surface-water withdrawal locations in Lonoke County, Arkansas, 1991

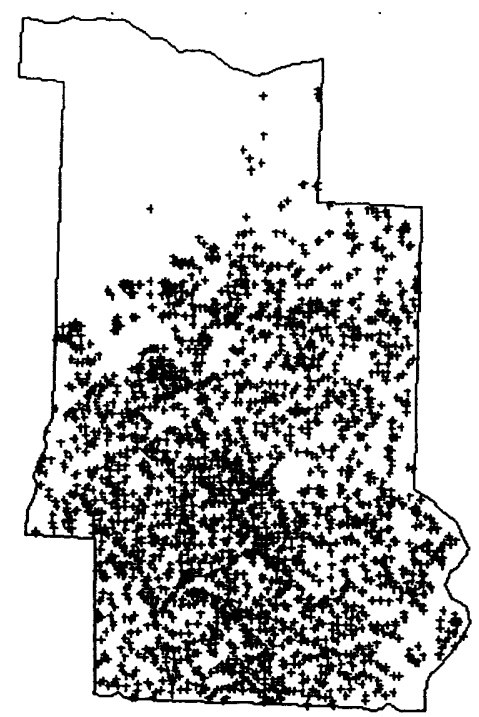

Ground-water withdrawal locations are represented by a "+".

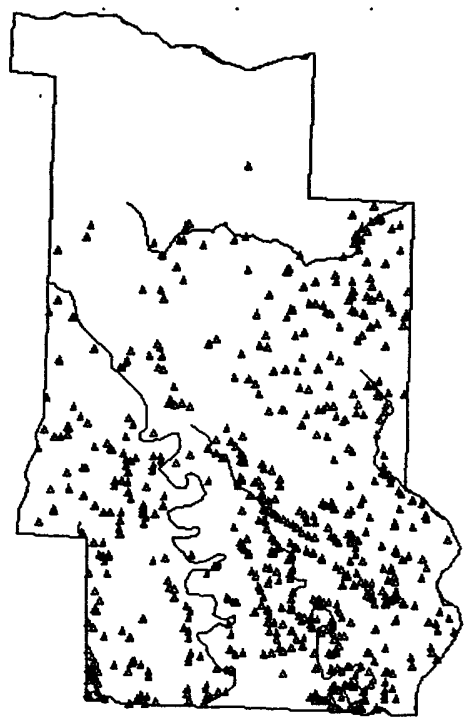

Surface-water withdrawal locations are represented by a " $\Delta$ ". 


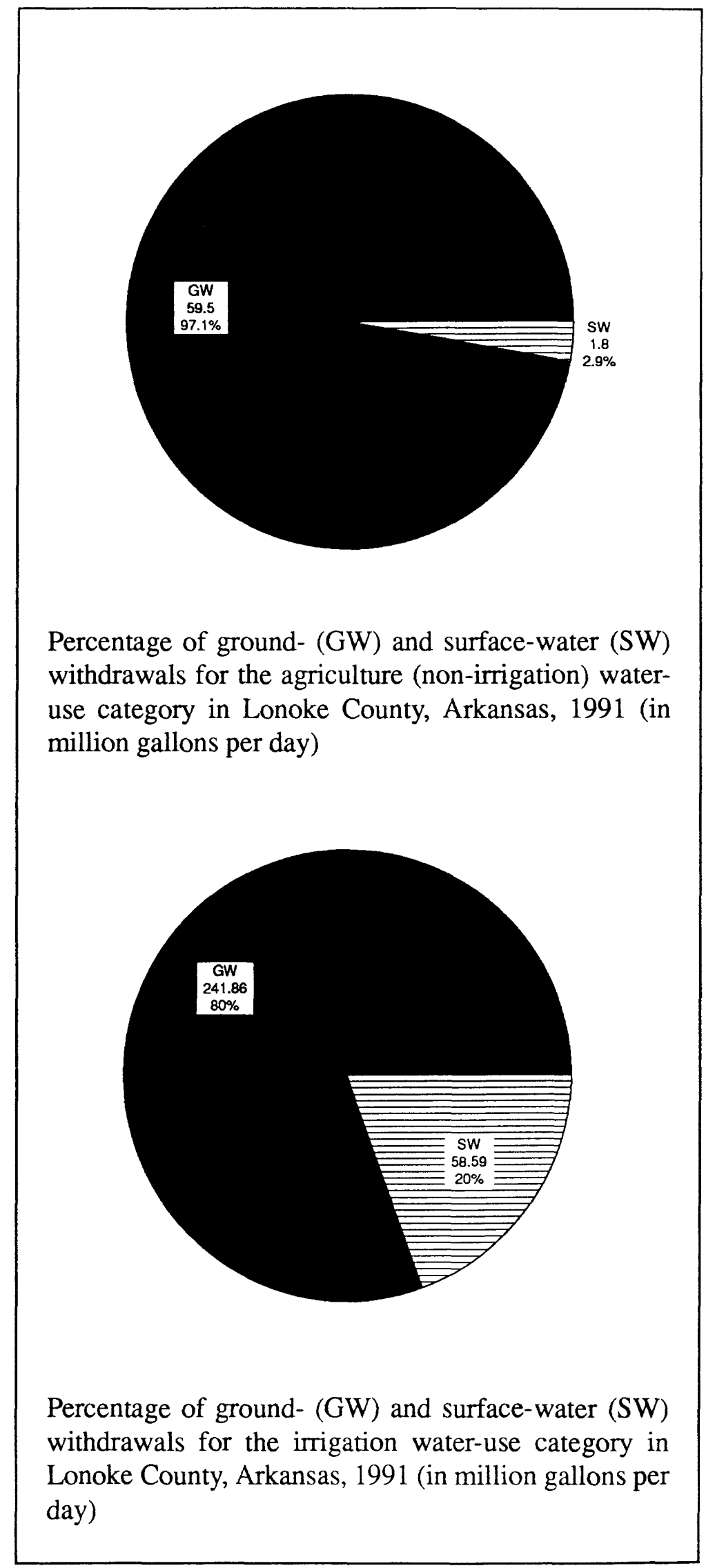




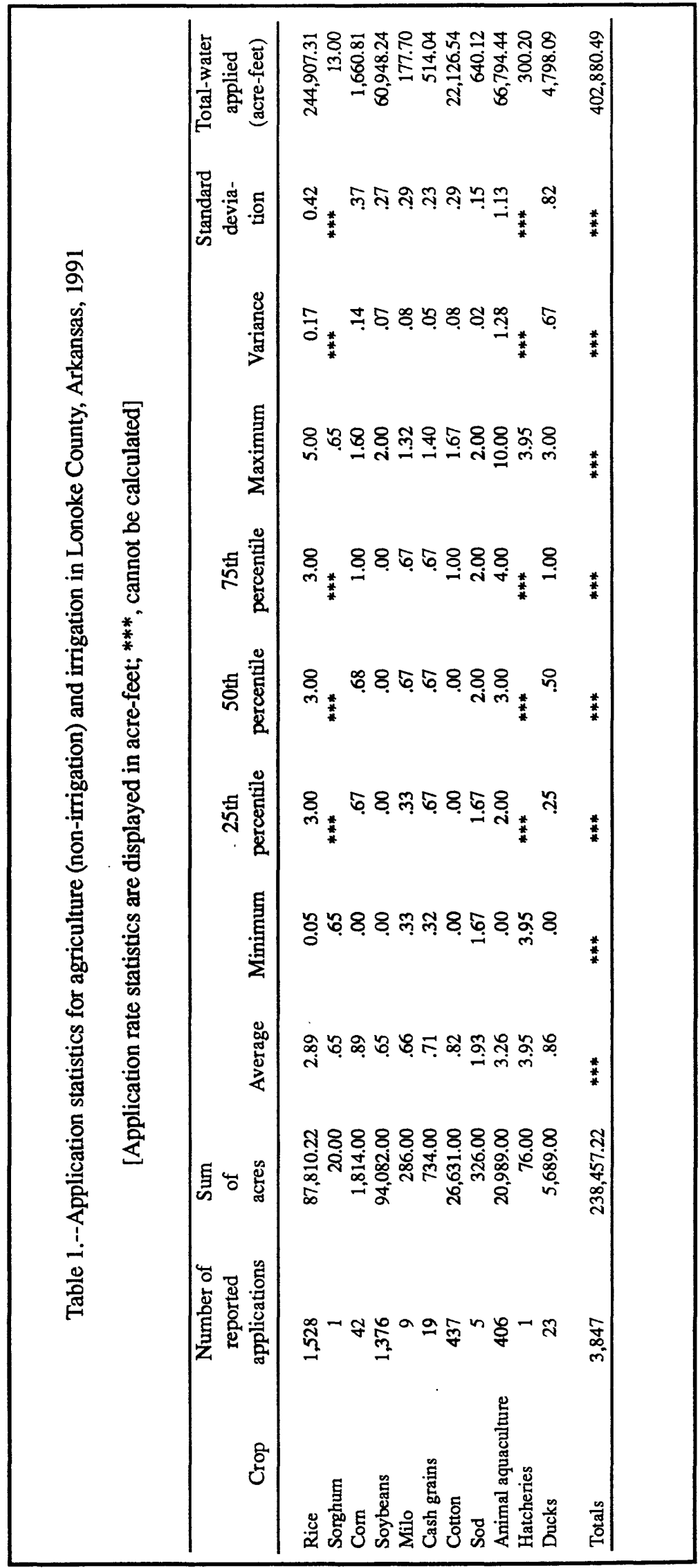




\section{Water-Use Reporting}

The information contained in this report was developed through a jointly-funded program with the Arkansas Soil and Water Conservation Commission to collect water-use data in Arkansas. The role of the U.S. Geological Survey is to compile and interpret these data. Inquires regarding additional water-resources information may be directed to:

\section{District Chief}

U.S. Geological Survey

2301 Federal Office Building

700 West Capitol Avenue

Little Rock, Arkansas 72201

In addition to the jointly-funded program to acquire water-use information, the Arkansas Soil and Water Conservation Commission has the responsibilities for water-use reporting under State law.

Act 81 of 1957, as amended, requires all diverters of water from streams, lakes, or ponds to register their diversion of surface water by quantity, location, type of use, and name of user on an annual basis with the ASWCC. The ASWCC is required to furnish each registrant a Certificate of Registration. The ASWCC utilizes these registrations for the allocation of water and as a basis for determining the State's overall water usage and water needs for inclusion in the Arkansas Water Plan.

Act 1051 of 1985 requires all users of ground water, excluding domestic use and wells having a maximum potential flow of less than 50,000 gallons per day, to register their withdrawal of ground water. The quantity, location, type of use, and name of user must be registered on an annual basis with the ASWCC or their local conservation district. 
Act 154 of 1991 provides the ASWCC the authority io develop a comprehensive ground-water protection program, designate critical ground-water areas, cost-share on installation of water conservation practices, establish ground-water rights within critical areas, establish fees for ground- and surface-water withdrawals, develop an education and information program, and delegate management powers to regional water districts and conservation districts. The intent of this program is to protect ground water for the future. The act also establishes as State policy, that if reductions in well pumpage are necessary, it is most desirable that the reductions come from conservation programs and the utilization of surface water. However, if necessary, the ASWCC may limit ground-water withdrawals through the issuance of water rights in critical groundwater areas.

Inquiries regarding additional information pertaining to State water law should be directed to:

Executive Director

Arkansas Soil and Water Conservation Commission

101 East Capitol Avenue, Suite 350

Little Rock, Arkansas 72201

There are several important facts that should be noted in reference to Act 154 of 1991:

1. The effective date of this act is October 1,1992 .

2. The act provides for the assessment of annual water-use fees in the amount of $\$ 10$ per registered surface-water diversion and $\$ 10$ per registered well, which is payable at the time of wateruse reporting.

3. Fees collected will be utilized for cost-sharing on waterconservation practices, administration, and education programs.

4. The period for registration and reporting extends annually from October 1 through March 31. 
For additional information write to:

District Chief

U.S. Geological Survey

2301 Federal Office Building

700 West Capitol Avenue

Little Rock, Arkansas 72201

Executive Director

Arkansas Soil and Water

Conservation Commission

101 East Capitol Avenue, Suite 350

Little Rock, Arkansas 72201

Copies of this report can be purchased from:

U.S. Geological Survey

Earth Science Information Center

Open-File Reports Section

Box 25286, MS 517

Denver Federal Center

Denver, Colorado 80225

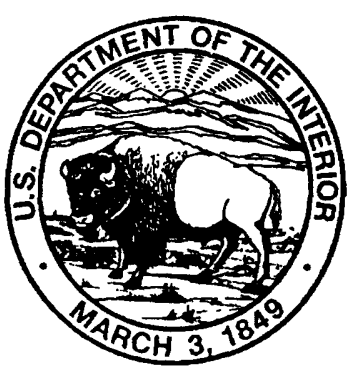

